\title{
Structure versus accident in the defeat of France's mainstream Right, April-June 2017
}

Article

Accepted Version

Knapp, A. (2018) Structure versus accident in the defeat of France's mainstream Right, April-June 2017. Parliamentary Affairs, 71 (3). pp. 558-577. ISSN 1460-2482 doi: https://doi.org/10.1093/pa/gsx044 Available at https://centaur.reading.ac.uk/73810/

It is advisable to refer to the publisher's version if you intend to cite from the work. See Guidance on citing.

To link to this article DOI: http://dx.doi.org/10.1093/pa/gsx044

Publisher: Oxford University Press

All outputs in CentAUR are protected by Intellectual Property Rights law, including copyright law. Copyright and IPR is retained by the creators or other copyright holders. Terms and conditions for use of this material are defined in the End User Agreement.

www.reading.ac.uk/centaur

\section{CentAUR}


Central Archive at the University of Reading

Reading's research outputs online 


\title{
Structure versus accident in the defeat of France's mainstream Right,
} April-June 2017

\begin{abstract}
Widely expected to recapture France's presidency and win a parliamentary majority in the 2017 elections, France's mainstream Right instead suffered a crushing and divisive defeat. A major reason for this was contingent: the selection of a candidate who three months before polling day was placed under investigation for embezzling public funds. Other reasons were more structural, in particular the progressive dislocation of the bipolar multipartism which had characterised France's party system for over four decades and the resultant strategic divisions within the Right. Although broadly chronological, this analysis of the long electoral cycle of 2016-17 assesses the respective importance of proximate and long-term factors in the Right's defeat.
\end{abstract}

Keywords: France, elections, presidential elections, parliamentary elections, rightwing parties

The French presidential and parliamentary elections of 2017 marked the end, temporary or permanent, of the bipolar multipartism which had characterised the party system since 1962 (Knapp and Wright, 2006, p. 260). It had been a multiparty system because up to five or six parties could compete within it and gain at least five per cent of the vote; because costs to new entrants were not prohibitive; and because parties periodically split, and sometimes merged. It was bipolar, in sharp contrast to the system of the Fourth Republic, because governing coalitions of Left or Right remained in place for the whole length of a parliament; because alternation in power was always between blocs of Left and Right, and never resulted from centre parties changing partners; and because 'grand coalitions' of centre-Right and centre-Left 
never governed. Bipolar multipartism was underpinned by a variety of dynamics linked to institutions (especially the two-ballot electoral system for parliamentary and presidential elections), voter behaviour, and party strategies.

By the early twenty-first century, and in particular from 2002 onwards, the system was under stress for reasons common to many European countries but strongly present in France: the strains placed on established parties by globalisation and Europeanisation; the emergence of new and disruptive political issues relating to immigration and national identity; and the corresponding rise of 'anti-system' parties of the far Right, most obviously the Front national (FN), and far Left. Held in check by France's institutional framework, these forces still found expression in voter disenchantment with politics in general and established governing parties in particular.

The established parties reacted with several techniques but limited success. When President Jacques Chirac engineered the creation of the Union pour un Mouvement Populaire (UMP) in 2002, he sought to overwhelm the FN by creating a strong, modern conservative party, ending what the voters saw as irrelevant competition between Gaullists and non-Gaullists (Haegel, 2002). But François Bayrou and his Centrists stayed out, and within the new party, deep underlying tensions remained without institutions to express, structure and limit them (Knapp, 2004, pp. 269-71). Five years later, Nicolas Sarkozy’s determined and skilful bid for FN votes was a short-term success but a longer-term failure. Primaries, and other means to give ordinary activists a bigger role, were also used by established parties in France and elsewhere to reconnect with their audience (Mair, Müller and Plasser, 2004); but they could engender their own destabilising dynamic. 
All of these factors made France's 2017 presidential and parliamentary elections deeply unpredictable. Under normal conditions of alternation in power, they were the mainstream Right's to lose. President François Hollande was so unpopular that he chose not to seek a second term. The chief party of the mainstream Right, Les Républicains (LR, as the UMP was renamed on 30 May 2015), and its close centrist allies, the Union des Démocrates et Indépendants (UDI), had several able, experienced contenders for the succession and an apparently robust method of choosing between them. Excellent local implantation promised to bear fruit in the parliamentary election. Yet by June 2017, the mainstream Right's prospects were in tatters: its presidential candidate eliminated in the first round - a first under the Fifth Republic -, its National Assembly representation cut by 40 per cent, and its unity shattered by the impact of a new president bent on 'recomposing' the party system. That President Emmanuel Macron had plucked the new prime minister, two key economic ministers, and two secretaries of state from LR was no consolation; for they became outcasts from their party.

Was the defeat structural or circumstantial? The structural context was the mainstream Right's limited popularity; the rise and consolidation of the FN; the resultant strategic tensions within LR/UDI, squeezed between far Right and Centre; and the unpredictable dynamic of the primaries. These considerations did not make defeat inevitable - the mainstream Right had won three of the five presidential elections since the FN's emergence in the mid-1980s - but they ruled out any automatic victory. Circumstance did the rest. It was the nomination as presidential candidate, however procedurally unimpeachable, of President Sarkozy's former prime minister, François Fillon, which turned an unpredictable electoral cycle into an unforeseeable disaster. 


\section{Poised for power? LR/UDI in 2016}

A year earlier, LR/UDI had appeared poised for power. One reason for this was negative: after January 2016 fewer than one in ten poll respondents expressed satisfaction with President Hollande's record (CEVIPOF, 2016-17, vague 14). As the President slid towards the abyss, the mainstream Right began its recovery from the two anni horribili that had followed the defeats of May-June 2012 (Knapp, 2014). Most obviously, the UMP/UDI started winning again. In the 2014 municipal elections they won 572 out of France's 932 towns of over 10,000 inhabitants, a net gain of 139. A year later they won control of 66 out of France's 101 départements (45 to the UMP, 14 to the UDI, and seven to non-aligned right-wingers labelled as divers droite), a net gain of 26. Finally, in December 2015 the Right won 7 of France's 13 new, larger regions, against just one out of the 22 old regions in 2010.

To a degree, organisational revival paralleled electoral recovery. A new generation of activists, many of them close to the Catholic Church, had gained experience in the Manif pour tous, the ultimately unsuccessful campaign against the Hollande administration's legalisation of gay marriage. The party leadership issue, a running sore since the botched election of the party president in November 2012, had been temporarily resolved in May 2014 when the party was taken over by three former prime ministers, Alain Juppé, Jean-Pierre Raffarin, and Fillon, pending a new election. Held in November 2014, this confirmed Sarkozy's return to front-line politics: the former president won a clear victory with 64.5 per cent of the vote against 29.2 per cent for former Agriculture Minister Bruno Le Maire and 6.3 per cent for former Overseas Territories minister Hervé Mariton (Le Monde, 29 November 2014). 
Just as important, the reform of the party statutes, and the crucial issue of how the next presidential candidate should be nominated, were unanimously entrusted to an impartial law professor, Anne Levade, whose committee opted for an open-primary system comparable to that used by the Socialists in 2011 . With the leadership question apparently settled, party membership rising, and a run of intermediate elections won, Sarkozy felt confident enough, on 30 May, to signal a break with the toxic events of 2012 by changing the party's name from UMP to Les Républicains.

The real situation was less rosy. Membership, having risen, stuck at 150,000, far short of Sarkozy's stated goal of 400,000 (France Inter, Interceptions, 8 November 2015; Le Figaro, 14 December 2016). Meanwhile, quarterly SOFRES polls showed poor opinions of the UMP/LR outnumbering favourable ones by an average of nearly 27 per cent across Hollande's presidency, an even worse score than that of the Socialists. Polls since at least 2010 showed the dominant feelings towards politics in general to be 'mistrust' and 'disgust' (CEVIPOF, 2017): a crisis, by no means confined to France (Pharr and Putnam, 2000), summarised by the pollster Brice Teinturier as 'Nothing left to do, nothing to do with us' (Teinturier, 2017). The problem was that LR, despite its successes, failed to break out of this ambient hostility.

The party's ongoing scandals hardly helped. These were scarcely new, as Philippe Madelin (2001) has demonstrated. Even in 1946, General de Gaulle, tutelary ancestor of LR, had said 'I don't like Gaullists because they are too fond of money' (Lacouture, 1985, p. 249). The issue that got Jean-François Copé, UMP president since December 2012, replaced by the temporary triumvirate of May 2014 was the illegal financing of Sarkozy's 2012 campaign, and in particular the use of a firm, Bygmalion, to charge a large overspend on public meetings to the UMP - illegally. 
Bygmalion also poisoned the party internally, since Sarkozy claimed that Copé had organised fake invoices for his own purposes. Other investigations into the UMP concerned presidential campaigns as far back as 1995, as well as close advisers to Sarkozy who were also pollsters and who had awarded themselves generous contracts for opinion surveys paid for by the Élysée. No change of brand could wipe clean this kind of dirt.

Even when it won elections, the UMP/LR attracted a mediocre vote share that barely measured up to the FN's in the first round (see Table 1). Only by adding in the UDI, the divers droite, and the hard-right Eurosceptics of Nicolas Dupont-Aignan's Debout la France, did the 'moderate' Right clearly outnumber its extreme adversary. Second round vote totals looked better because many left-wing voters rallied, where necessary, to the mainstream Right in a 'republican front' to defeat the FN; but this was a far cry from the UMP's founding ambition of 2002.

Table 1: Right-wing and extreme-right votes at intermediate elections, 2014-15 about here

The UMP/LR's failure to contain the FN presented an obvious strategic dilemma: whether to pitch openly for far-right votes, as Sarkozy had usually done since 2007, or to reaffirm the political, economic and moral differences separating the two sides of the Right, on the assumption that elections were still won at the centre. This dilemma, reinforcing and reinforced by personal clashes, had divided the mainstream Right since the FN's early breakthroughs in 1983-84, but had grown in intensity since 
Marine Le Pen had established a new electoral base line of 20 per cent for her party. Poised for power, then, the mainstream Right may have appeared in 2016. But it also suffered from a tarnished image, underlying electoral weaknesses, fierce personal rivalries, and clear strategic divisions. All would be fully exposed by the long electoral cycle of 2016-17.

\section{The Primary, 20 and 27 November 2016}

For a party to adopt open primaries is not a neutral choice: they take candidate selection out of the hands of party apparatuses and of rank-and-file party members and place it with the wider circle of party sympathisers. This broad, unpredictable group may, however, serve the party as a whole by looking beyond partisan conviction to electability; and a big, successful open primary may attract positive voter attention, enhancing the ensuing election result. That was how Hollande had won the presidency in 2012. Equally, however, such a primary dividend may be reversed if candidate competition is too bitter (De Luca and Venturino, 2017).

The principle of a primary, part of the agreement reached to save the UMP from disintegration in 2012, appeared in its new statutes in June 2013 (Le Monde, 17 December 2012; 28 June 2013) and in those of LR two years later (Les Républicains, 2015). The primary would be open to anyone who declared support for the values of the Right and the Centre and paid two euros (Le Monde, 7 April 2015; Charte de la Primaire, 2015). Within the UMP, the open primary appealed more to moderates, anxious to widen candidate choice beyond the hard-line supporters of Copé or 
Sarkozy, than to true believers. But for the party as a whole, it may be seen as a calculated risk taken to defuse the ferocious rivalries at the party's heart.

The conviction/electability dichotomy was encapsulated by the two candidates who between them commanded two-thirds of voting intentions in the first half of 2016, former President Sarkozy and former Prime Minister Juppé. Though defeated, Sarkozy retained his place in UMP sympathisers' affections: in March 2013, 57 per cent of them wanted him as their candidate for 2017, and 60 per cent wanted a president who, like Sarkozy, would apply a clearly right-wing programme. But he worried or angered nearly half of the wider population (IFOP, 2013; 2014a). Across the general public, by contrast, Juppé was one of IFOP's five most popular French politicians from November 2012; centrists liked him more than did UMP supporters, and Socialists almost as much (IFOP, 2016a). His record as mayor of Bordeaux was applauded nationally. Credited in November 2014 with 28 per cent of the presidential vote, if nominated by the UMP, to Sarkozy’s 26, Juppé also, unlike Sarkozy, appeared capable of ensuring that the non-aligned centrist, François Bayrou, would not compete (IFOP, 2014b). Small wonder that the Juppé camp lobbied (successfully) for the primary to be open to sympathisers of the 'Right and Centre' and not just the UMP (Édouard Philippe, interview, 6 January 2015).

Juppé's rise to popularity - after a career marked by deep discredit during his period as prime minister in 1995-97, plus a conviction for misuse of public funds in 2004 (Dive, 2016) - was at the expense of Fillon. Fillon had suffered badly from the bruising contest with Copé for the party presidency in 2012. Henceforth he began to abandon his earlier 'social Gaullist' stance and reposition himself as a firm conservative. In September 2013 he recommended that UMP voters obliged to choose 
between an FN and a Socialist in a second-round run-off should back 'the less sectarian' of the two (Le Monde, 9 September 2013). In June 2014 he unveiled an explicitly Thatcherite 'programme de rupture' to cure France's economic ills (Le Monde, 10 May 2016). A year later, his book Faire (Fillon, 2015) linked a (discreet) account of his premiership to a declaration of his Catholic faith and to economic proposals that would feed into his campaign. In the short term, little of this worked: in spring 2016, the primary still appeared as a two-horse race, with Fillon struggling to reach double figures.

Yet it was Fillon who on 27 November, by a two-thirds majority in the second round, was nominated the official candidate of LR/UDI (see Table 2). Probably not even Fillon himself had expected this outcome. Six explanations may be offered.

Table 2: Results of the Primary of the Right and the Centre, November 2016 about here

First, polls since 2014 had invariably forecast both Marine Le Pen's qualification for the second round and a comfortable victory for whichever mainstream candidate reached the run-off to oppose her. The strong likelihood of a Right/far Right run-off devalued Juppé's popularity with Centre voters. Second, in the (self-critical) view of a key campaign organiser, Juppé failed to understand this, and instead pitched to the left wing of the primary electorate rather than the LR mainstream (Édouard Philippe, interview, 11 January 2017). His slogan 'l'identité heureuse', a celebration of French 
diversity, left mainstream electors cold and Juppé open to accusations of naïveté, and worse: the nickname 'Ali Juppé' began to circulate on social media.

Third, Sarkozy's attempt to blast his competitors out of the primary from late August 2016 gained little traction. His continuing judicial difficulties were an unwelcome distraction. On 1 July he was placed under investigation for 'active corruption' - allegedly offering a judge a post in Monaco in exchange for sensitive information (Le Monde, 24 August 2016). Two months later, the prosecution service recommended he be tried over the Bygmalion case. Meanwhile Sarkozy used the socalled 'burkini affair', a silly-season news story about Moslem women's enveloping swimwear, as well as the ongoing Mediterranean refugee crisis, to bid for the FN leaners who would vote at the primary, with proposals such as a partial end to France's traditional jus solis as a basis for nationality and restrictions on families' rights to join migrants resident in France (Le Monde, 12 September 2016). Like Juppé, Sarkozy neglected the LR mainstream. Polls predictably showed Juppé's support strongest among centrists and even left-wingers, Sarkozy's concentrated on the fringes of the FN, each in his way fighting an imaginary, and premature, campaign for the run-off of the presidential election - and only Fillon's camped firmly at the LR centre of gravity (IFOP, 2016b).

Fourth, Fillon used his outsider status to land blows on the other candidates while largely escaping their attention, mocking Sarkozy for 'rushing to Mass on 15 August [Ascension Day] after summoning photographers'. Juppé had a past conviction; Sarkozy faced possible prosecution; only Fillon had a clean record, as he constantly reminded LR voters. 'Who', he pointedly asked, 'could imagine even for a moment General de Gaulle placed under judicial investigation?' (Le Monde, 28 and 29 August 
2016). His opponents found this hard to counter; and in any case, Sarkozy and Juppé mostly attacked one another.

Fifth, Fillon, with the zeal of a convert from 'social Gaullism' to declared Thatcherism, set the economic agenda. His programme included spending cuts of $€ 110$ billion and a reduction of 500,000 public-sector posts in five years, a shift in the fiscal burden from direct to indirect taxation, the end of the wealth tax and of the 35hour week, limitations to health cover by the overstretched social security system, and the raising of the retirement age to 65 by 2022. Every other candidate announced comparable measures, but Fillon had been the first and most radical (Le Monde, 21 January, 1 September, and 23 November 2016). Juppé, it is true, would attack his proposals as 'brutal' between the two rounds of the primary, but by then it was too late. Finally, Fillon's much-declared Catholicism attracted former supporters of the Manif pour Tous. They represented a good third of LR sympathisers, but were especially likely to vote; over four-fifths backed Fillon at the second ballot (IFOP, 2016c; 2016d).

Unlike his two main rivals, then, Fillon sensibly appealed, not to centrist or farRight voters, but to the centre ground of the right-wing electorate: ageing, comfortably-off, Catholic, socially and economically conservative. An understated personality and a (constructed) reputation for probity did the rest - but only at the very end of the campaign. It was mid-November before he grabbed enough support 15 extra points in under a month - to close with his main rivals, at 27 per cent to Juppé's 31 and Sarkozy's 30 (CEVIPOF, 2016-17, vague 8; IFOP, 2016b; 2016e). Even with this trend, Fillon's commanding first-round result, almost certainly fuelled by an unexpectedly high turnout, was a surprise. Over 15 points ahead of Juppé, over 
23 points ahead of Sarkozy, who was now eliminated, he led in 479 out of 577

parliamentary constituencies and 89 out of 96 metropolitan départements. To win at the run-off, Juppé needed nearly all of Sarkozy's voters - an impossibility given the opposition between the two electorates. Attracting even one third of the second-round vote was a relief to the Juppé team.

In several respects the primary had been a resounding success. Fair and wellmanaged, unlike the 2012 contest for the party presidency, it had attracted both media attention (in four televised debates) and some nine per cent of all registered voters. It had produced a clear result. And the two-euro contributions translated into a net profit to LR of some nine million euros. One shortcoming was immediately identifiable: the primary had attracted far more well-off retired voters than ordinary wage-earners (IFOP, 2016b). A second failure took longer to emerge: the voters had unwittingly made a disastrous choice.

\section{The fall of Fillon, December 2016-April 2017}

In early December 2016, with Marine Le Pen apparently guaranteed a place in the second-round run-off but unelectable, the Socialists in disarray, and Macron an unknown quantity, Fillon was odds-on favourite to be France's next president. His victory in the primary, followed by his publication of a book on 'Islamic totalitarianism' (Fillon, 2016), raised his voting intentions from 20 per cent in midNovember to 29 per cent two weeks later, comfortably ahead of Le Pen. This did not last. As Figure 1 shows, Fillon's support fell back in two step changes in two months, never to recover. 
Figure 1: Voting intentions for three major candidates, November 2016-February 2017 about here

The first drop occurred within weeks. By early January, at 24 per cent of voting intentions, Fillon, though still a likely qualifier for the run-off and a likely winner against Le Pen, had lost his commanding lead. Two explanations may be offered. The first concerns Fillon's organisation of LR and his campaign team. Under party statutes (article 39-4), he became de facto party leader as winner of the primary. But his transfer of the interim leader, Sarkozy supporter Laurent Wauquiez, to the honorific title of vice-president, and the exclusion of Juppé backers like Édouard Philippe from senior posts, aggravated rather than pacified divisions left by the primary (Le Monde, 30 November 2016). Fillon then took two weeks to build a campaign team, which at 90 strong appeared to privilege inclusivity over effectiveness; insiders confided that only twenty people in it really counted (Le Monde, 16 December 2016).

Secondly, as Fillon's programme came under close media scrutiny, policy problems compounded those of organisation. In particular, his proposal to 'focus universal public health insurance on serious or long-term illnesses, and leave the rest to private insurance' was a gift to his opponents. By 13 December it had disappeared from the Fillon website, and the candidate was claiming that 'at no moment have I wished to privatise health insurance' and that 'I do not wish to distinguish between major and minor health risks'. But what he did propose remained unclear (Le Monde, 
13 and 15 December 2016). A month later, leading members of the campaign team such as Bernard Accoyer, Bruno Le Maire, Gérald Darmanin, mayor of Tourcoing, or former budget minister Éric Woerth, were still tripping over one another on issues ranging from the working week for public employees to the use of ethnic statistics. Wauquiez, meanwhile, was publicly criticising Fillon's campaign (Le Monde, 18 and 20 January 2017).

By then, Macron, officially a candidate since 16 November, was shaping up as an unusually strong competitor from the Centre. It remains possible that Fillon's alarming programme, his sprawling campaign team, and the attractiveness of both Macron and Le Pen, would have sufficed to squeeze him into third place in any event. What made this outcome a near-certainty were the revelations about Fillon's financial affairs published on 25 January by the satirical weekly newspaper Le Canard enchaîné. Here was the second step drop: Fillon now fell behind Macron, and would never rise above 22 per cent, or regain second place, before polling day on 23 April (CEVIPOF, 2016-17, vagues 11-13).

The newspaper established that between 1988 and 2013 Fillon's British wife, Penelope, had been employed as a parliamentary assistant both for him and, during his periods in government, for his substitute as député for the Sarthe, Marc Joulaud. This cost the taxpayer about $€ 1.5$ million for her pay plus social contributions - well above normal rates. And although parliamentarians were permitted to employ family members, there was no evidence that she had earned her pay. Indeed, in $2007 \mathrm{Mrs}$ Fillon had told the Daily Telegraph that 'I've never been actually his assistant or anything like that' (Daily Telegraph, 2017). She had also been employed by the Revue des Deux Mondes, a conservative periodical owned by Fillon's friend Marc Ladreit de 
Lacharrière, for a total of $€ 100,000$ between 2012 and 2013, again for no apparent work. Fillon had also employed his children Marie and Charles between September 2005 and June 2007, supposedly as lawyers, although neither had yet qualified. Fillon himself, meanwhile, had received an undeclared loan of $€ 50,000$ from Ladreit, plus gifts of two tailor-made suits worth $€ 13,000$ and a watch worth $€ 10,000$ from two different businessmen (Le Monde, 27 January, 1 and 7 February, 14, 16, 18 and 25 March, 14 April 2017).

Hours after the first Canard enchaîné article appeared, the prosecution service opened a preliminary enquiry. Fillon was issued a summons on 1 March and placed under investigation for embezzlement of public funds two weeks later. Formal investigations were extended to Penelope Fillon and Marc Joulaud on 24 and 28 March, and later covered the gift of suits, and possible forgeries undertaken by the couple to cover their tracks (Le Monde, 21 March and 12 April 2017). Few imaginable sequences of events could have done damaged Fillon's candidacy more. Fillon himself had placed his own integrity at the heart of his primary campaign. Nearly two-thirds of the French put honesty and probity at the head of the qualities they required in a president (IPSOS, 2017a). Yet his alleged offences looked worse than those of Sarkozy and Juppé, whose misdeeds were limited to political finance; for Fillon appeared simply to have lined his own pockets, and his family's.

His own reactions, histrionic and inconsistent, compounded the damage. Initially stating his confidence in French justice and undertaking to step aside if placed under investigation, he then claimed, via his lawyers, that the prosecutors' actions were illegal - and when summonsed on 1 March, reneged on his earlier promise and refused to stand down under any circumstances. He went on to accuse President 
Hollande of organising a 'dirty tricks office' in the Élysée to persecute him, and declared himself the victim of a 'political assassination' (Le Monde, 1, 7 and 24 March and 6 April 2017). Yet he also conceded 'mistakes' in employing his family, even for 'indispensable' work, and in accepting the suits - which were finally returned to their donor (Le Monde, 6 February, 2 and 25 March 2017). His campaign, meanwhile, shifted from economic and fiscal reform towards hard-right themes of security, national identity and (a characteristically FN slogan) 'anti-French racism' (Le Monde, 12 and 22 March 2017); in weeks, the most sober of mainstream candidates turned into a ranting populist, who turned down an interview with $L e$ Monde stating that 'it was not for journalists to choose the questions' (Le Monde, 20 April 2017). The public was unconvinced. Early in February, 77 per cent of poll respondents (and 59 per cent of LR sympathisers) expressed 'anger' and 'frustration' at the revelations, against just 11 per cent (34 per cent among LR supporters) who thought Fillon unfairly treated. Three weeks later, just 23 per cent thought that he should maintain his candidacy (CEVIPOF, 2017, vagues 11-11bis).

Meanwhile, Fillon's activists fell away and campaigning in the provinces ground to a near-halt. Demonstrators, equipped with saucepans, a noisy symbol of his guilt, or eggs or flour for throwing, dogged his rare public appearances (Le Monde, 6 and 11 February, 25 March and 7 April 2017). After 1 March, senior Fillon supporters began to defect, including Patrick Stefanini, his campaign director, Thierry Solère, the organiser of the primary, as well as Bruno Le Maire, the UDI centrists and some 300 LR elected officials. Juppé assumed a low profile. Major figures from the Chirac generation, including former prime minister Dominique de Villepin, simply went over to Macron (Le Monde, 24 March 2017). 
Yet plans for a coup to replace Fillon as nominee, though prepared discreetly, were abandoned on 6 March when Juppé announced that he would definitely not run. Fillon carried on, with a reduced campaign team headed by Bruno Retailleau and former Finance Minister François Baroin. Increasingly prominent among his shrunken but fervent band of followers was Sens Commun, a Catholic spin-off from the Manif pour tous (Le Monde, 14, 15, 17 and 19 April 2017). The proximate reason for Juppé's decision was Fillon's successful rally in a rainy Place du Trocadéro on 5 March (Le Monde, 6 March 2017). More fundamentally, however, Fillon was impossible to dislodge. Neither the party statutes nor the charter of the primaries contained any such provision; and Fillon controlled the party apparatus. For another candidate to run independently against him would merely have split the LR vote, with the challenger taking the blame. Moreover, the campaign chest of some $€ 17.5$ million had been paid into Force Républicaine, a micro-party set up for the purpose, which Fillon controlled. No challenger could match such sums in seven weeks. As the LR Deputy Georges Fenech observed, Fillon 'had us by the throat' (France 3, 2017; Le Monde, 10 May 2017). With no Plan B available, Fillon's campaign stabilised as Sarkozy and Juppé showed public, if not enthusiastic, support (Le Monde 7 and 19 April 2017). The polls closed up momentarily and Fillon claimed that a 'hidden rightwing vote' would sweep him to the run-off. His hopes were to prove misplaced.

\section{Elimination, 23 April}

From 1958 to 2012, a mainstream right-wing candidate had reached the run-off of every French presidential election. Not so Fillon in 2017. Given the enveloping swirl of sleaze, however, his 7.2 million votes appeared almost impressive. Compared with 
General de Gaulle and Georges Pompidou in the Gaullist heyday of the 1960s, or with the talented Sarkozy, Fillon's percentage is certainly mediocre (see Figure 2). But it was comparable to those of Chirac between 1981 and 2002, the last two of which had opened the path to the Élysée, and five points better than the historic Gaullist Jacques Chaban-Delmas, who had achieved barely 15 per cent in 1974 against a Macron-like candidate of the liberal, pro-European centre-right, Valéry Giscard d'Estaing.

Figure 2: Scores of 'Gaullist' candidates at presidential elections, 1965-2017 (\% of votes cast) about here

Yet Fillon's support, like Chirac's, suffered from grave weaknesses. Geographically, the Fillon vote resembled a badly moth-eaten version of the Right's traditional areas of strength (Knapp and Wright, 2006, p. 269); and he led the field in just 47 out of 577 parliamentary constituencies (IFOP, 2017a). Sociologically, Fillon's voters looked like a caricature of conservatism. Every right-wing electorate is a composite of older, socially conservative groups and younger categories drawn to the Right through hostility to state interventionism: Chirac's steady level of support concealed a changing composition - older and conservative in 1988, younger and more dynamic in 1995. Fillon's electorate regressed to Chirac's 1988 pattern. He attracted just 20 per cent of professional and managerial voters, 11 per cent of all wage- and salary-earners, and a mere 5 per cent of blue-collar workers. But he was backed by 25 per cent of persons with a monthly income of over $€ 3,000,29$ per cent of small business owners, 36 per cent of the retired, 39 per cent of over- 65 s, over half of regularly practising 
Catholics, and 46 per cent of supporters of the Manif pour Tous. Perhaps most strikingly, over 52 per cent of Fillon voters were retired, and over 45 per cent were over 65, against 13.5 per cent of under-35s (IFOP, 2017b; 2017c; 2017d; IPSOS, 2017b). Quite distinct from the younger, less educated, more rural, more workingclass Le Pen vote, Fillon's was the traditional Right reduced to its comfortably-off, elderly, Catholic baseline. It was a defiant electorate: whereas most voters favoured probity as a president's first quality, only 19 per cent of Fillon supporters did so (IPSOS, 2017a). This was not a strong basis from which to campaign in the June parliamentary election, which after the first-round presidential defeat became the mainstream Right's sole remaining hope.

\section{The fault-lines open, 23 April-7 May}

If the only problem in the presidential race had been the candidate, reasoned senior LR figures, the parliamentary election might still be winnable; hence the noisy agreement of Woerth, Fenech, or Darmanin when Fillon took personal responsibility for his own defeat (Le Monde, 24 April 2017). But such a viewpoint ignored the mainstream Right's long-term divisions, which Fillon's candidacy had accentuated as his campaign radicalised. These now emerged with the awkward question of the presidential second round. The mainstream Right and Left had often co-operated to defeat any FN candidate present in the second round of local and parliamentary elections. However, the 'republican Front' strategy, never official, had always caused unease among some right-wing candidates and voters; in by-elections in 2011, it had been replaced by a 'neither Left nor FN' line. Squeezed out of the presidential race, but retaining hopes for their National Assembly seats, should LR now back Macron, 
or a blank vote, or even Le Pen? In an editorial immediately after the presidential first-round defeat, the right-wing daily Le Figaro called a republican front to back Macron a 'trick' (Le Figaro, 24 April 2017). Many LR supporters agreed.

Within the LR galaxy, only Christine Boutin, the ultra-Catholic leader of the small Parti Chrétien-Démocrate, opted for Le Pen. But figures on the right of LR, including Retailleau, Wauquiez, and the influential Nice Deputy Éric Ciotti, opposed backing Macron openly. That, they claimed, would alienate the party's FN leaners: better at least to reassure them that a spoilt ballot was acceptable. Against them, all the leading competitors in the primary - Fillon, Juppé, Sarkozy, and Le Maire, plus other figures such as Raffarin - called unambiguously for a Macron vote. On 24 April the LR bureau politique resorted to a fudge: while ruling out abstention, it invited voters to 'defeat Le Pen' without mentioning Macron's name (Le Monde, 25 April 2017).

The campaign between ballots was complicated by Nicolas Dupont-Aignan, leader of Debout la France, who had won 4.70 per cent of the first-ballot presidential vote. On 29 April he declared for Marine Le Pen, in exchange for the post of prime minister if she won. Dupont-Aignan was a small catch for the FN, and Debout la France, which had no direct links to LR, was hardly a real party. In the end DupontAignan and Boutin remained isolated. Still, an external organisation had rallied to an FN candidate for the first time in 45 years; to that extent, a taboo had been broken.

The second round of the presidential contest now offered a full-sized, national demonstration of the attractiveness of Marine Le Pen to voters of the mainstream Right (see Table 3). In 2002, when voters had a second-round choice between Chirac and Jean-Marie Le Pen, Le Pen's support had risen only marginally between the two 
rounds, most of the extra votes coming from the dissident FN candidate Bruno Mégret. Chirac, by contrast, had gained nearly 20 million votes thanks to Left and Centre voters, and former abstentionists, who mobilised against a candidate seen as a danger to democracy.

Table 3: Votes for the two leading presidential candidates, 2002 and 2017

These reflexes were far less effective in 2017, when the mainstream Right rather than the Left had been eliminated. Marine Le Pen gained nearly three million votes, and over 12 percentage points, between the two rounds; Macron's gains were correspondingly less impressive than Chirac's. Le Pen drew second-round support from the hard Left, whose candidate, Jean-Luc Mélenchon, had not endorsed Macron, and from the Socialist Benoit Hamon, who had; but the largest group (see Table 4) came from the mainstream Right. Only half of Fillon voters followed the party's call to defeat Le Pen, over a quarter abstained, and at least a fifth switched to the FN candidate. Dupont-Aignan voters were fewer but, logically, more inclined to support Le Pen. Table 4 thus illustrates the dilemma of France's mainstream right. LR cannot afford to push its FN leaners into the arms of Le Pen; but undue efforts to placate them would lose support to the Centre, and especially to such an apparently attractive proposition as Macron's La République en Marche (LRM). That was also to be LR's problem in the parliamentary election. 
Table 4: Where the votes went, 7 May 2017 (as \% of first-ballot vote share) about here

\section{Limiting the damage: the parliamentary election, 11 and 18 June}

Since 1981, every presidential election but one has been followed by a parliamentary election. With equal regularity, losing parties have invited voters to 'balance' the elected president's power with a hostile majority - as unsuccessfully in 2012 as in 1981, 1988, 2002, or 2007. Baroin, unanimously chosen by the LR bureau politique of 2 May to lead the 2017 parliamentary campaign, did not deviate from the rule, setting his objective as a National Assembly majority for LR and the post of prime minister for himself. Perhaps, LR reasoned, they had a chance if Fillon had really been an accident and if they could dump elements of his hair-shirt programme such as the two-point VAT rise or the speedy cut in the public service head-count (Le Monde, 9 May 2017). After all, they were France's best-implanted party locally, whereas LRM was starting from scratch. And the FN, floundering after Le Pen's mediocre presidential result, appeared less dangerous.

The traditional dynamic of 'confirmation' elections, however, soon reasserted itself. Indeed, Baroin's opposition line was immediately contested by centre-Right figures in LR like Le Maire, who talked of 'working with' Macron in the future (Le Monde, 3 May 2017). Alongside LR's FN leaners, then, Baroin faced the emergence of the 'Macron-compatibles'. And LR had a mountain to climb, since new restrictions on combining local and national elective offices devalued LR's local implantation. 
Moreover, the new president, in office from 14 May, aimed to transform French politics at the expense of the established parties.

The first step in Macron's project was the appointment as prime minister of Édouard Philippe, LR Deputy and mayor of Le Havre and a leading organiser of Juppé's primary campaign. Into Philippe's government, alongside former Socialists and non-party figures, came Le Maire and Darmanin - both to major economic posts. Predictably and intentionally, these appointments destabilised LR. Some 173 leading party figures, including Solère and former Environment minister Nathalie KosciuskoMorizet, called on the party to take a constructive approach to the new government (Le Monde, 15 and 17 May 2017; L'Express, 17 May 2017). This group had organised before 23 April, and now campaigned on the LR ticket while insisting on their right to vote for the Philippe government when they chose. Macron's team ensured that among this 'constructive' group, fifteen parliamentary candidates in mainland France plus a handful overseas, faced no LRM candidate (Le Monde, 6 June 2017): an affront both to right-wingers like Wauquiez or Ciotti and to the Baroin leadership, still wedded to frontal opposition.

That line never corresponded to the public mood. Even in the event of an LR victory, 71 per cent of respondents (and 49 per cent of LR supporters) told IFOP late in May, that they would prefer Philippe to Baroin as prime minister. And in any case in opinion polls LR/UDI/divers droite trailed LRM by 20.5 points to 31 in May (IFOP, 2017f). In the first round on 11 June, in a poll marked by unprecedented abstention, the mainstream Right obtained 4,885,997 votes ( $21.66 \%$ vote share). This electorate, smaller than Fillon's, was marked by the same social pattern of support: 29 per cent of the retired, but 14 per cent of the economically active (IFOP, 2017g). A week later, a 
small increase of 12,000 votes sufficed, in a context of even lower turnout, to ensure a vote share of 26.95 per cent - and, crucially, to save seats. The mainstream Right's total of 135 members of the new National Assembly compared poorly with the outgoing total of 227 , but well with the 80 seats predicted by some polls. These predictions had probably helped shape the final result: with LRM expected to take 400 seats, many Macron voters did not trouble to vote in the second round, while those of LR were finally mobilised by Baroin's warning of the risks (Le Monde, 20 June 2017).

The mainstream Right had still suffered a second heavy defeat. And like the Socialist Party (PS), having held together for the electoral cycle, it now began to break apart. The precipitating issue was whether to offer implacable opposition or conditional support to the new president and government. That split the LR Deputies: 100 formed the main LR group, but eighteen joined the UDI in a more pro-Macron group, 35 strong, called Les Constructifs: républicains, UDI, indépendants. Underlying this separation lay years of tensions between moderate and hard-line elements which exploded on 12 June (Le Canard Enchaîné, 14 June 2017). For most of LR, Philippe, Le Maire, and Darmonin, plus the two junior ministers who joined them in the second Philippe government, had betrayed their party. So had Solère, who with LRM support would secure election to the coveted position of quaestor of the National Assembly, a post normally reserved for the opposition. Their exclusion from LR was placed on the July agenda of the bureau politique. On the Constructifs side, former Prime Minister Raffarin observed that he saw no reason to oppose a government whose programme he approved of, while Xavier Bertrand, president of the Hauts-de-France region, accused LR hardliners of 'cutting the party off from society' and added that there was 'no longer much in common' between him and those like Wauquiez who went 'running after the far Right' (Le Monde, 27 June 2017). 
The extension of the parliamentary-level split into a full-scale division into two parties now appeared highly likely.

\section{Conclusion: the Right and Recomposition}

The new president's aim was to reconfigure the whole party system and govern France from the centre. When Valéry Giscard d'Estaing (1985) had attempted this forty years earlier, the Left-Right division in French politics had corresponded to profound divisions among voters (Capdevielle et al., 1981, pp. 251-56); by the twenty-first century, this was less true and the context correspondingly more promising. Bipolar multipartism had become more vulnerable to crises within the established parties, to accidents, and to determined attacks from outside. All were present in the perfect storm of 2016-17. First, the crisis in the PS made the elimination of any Socialist candidate a near-certainty for 2017. Second, the strong probability of an unelectable candidate, Marine Le Pen, qualifying for the second round meant that the result would not be determined by a conventional Left-Right run-off in which centre votes are pivotal. This affected the primaries: neither Hamon for the Socialists nor Fillon for LR was chosen to appeal to centre voters. Third, the nomination of Fillon was 'accidental' insofar as it was made without knowledge of his personal financial affairs. His penchant for Thatcherite rigour and his shambolic campaign organisation might in any case have sunk him; but once it became clear that austerity stopped at the Fillon home, his chances disappeared - and no Plan B was possible without Fillon's consent. Into this breach stepped Macron. His first-round victory, just four points ahead of Fillon, was scarcely overwhelming. Yet it was still the best result of any Centre candidate during the Fifth Republic. Above all, it 
unlocked everything else: the resounding second-round presidential victory, the overall parliamentary majority, and the recomposition, with bipolar multipartism replaced by a president and party straddling the Left-Right divide.

In this context the future of France's mainstream Right appeared bleak: not returned triumphantly to power, but relegated, again, to opposition; not united, but liable to a long-term, structural split. Nor can the Right count on a swing of the pendulum in 2022. For what Macron appears to want is a permanent domination by the Centre, with opposition confined to the extremes of Left and Right, with both PS and LR, the two pillars of bipolar multipartism, effectively eliminated. In principle, such a perspective appears not only unhealthy for French democracy but also unlikely in the long term: the institutional logic of the Fifth Republic arguably promotes LeftRight confrontation, and Macron and Philippe are no more immune to drops in popularity than Hollande or Valls, Sarkozy or Fillon. Whether the mainstream Right is ready to draw the benefits as and when the Macron spell is broken remains, however, very much an open question.

\section{References}

Capdevielle, J., Dupoirier, É., Grunberg, G., Schweisguth, E., and Ysmal, C. (1981) France de gauche, vote à droite. Paris, Presses de Sciences Po.

CEVIPOF (2016-2017) 'L’Enquête électorale française 2017’. Accessed 2 June 2017. https://www.enef.fr/données-et-résultats 
CEVIPOF (2017) 'Baromètre de la confiance politique, vague 8'.

http://www.cevipof.com/fr/le-barometre-de-la-confiance-politique-ducevipof/resultats-1/vague8/ Accessed 29 May 2017.

Charte de la Primaire (2015) 'Primaire ouverte de la droite et du centre'. www.primaire2016.org/charte Accessed 31 May 2017.

Daily Telegraph (2017) Penelope Fillon interview from May 2007. http://www.telegraph.co.uk/news/2017/02/02/never-assistant-francois-fillonstold-telegraph-presidential/ Accessed 31 May 2017.

De Luca, M., and Venturino, F. (2017) 'The effects of primaries on electoral performance: France and Italy in comparative perspective.' French Politics 15.1, $43-56$.

Dive, B. (2016) Alain Juppé: l’homme qui revient de loin, Paris, L'Archipel.

Fillon, F. (2015) Faire, Paris, Albin Michel.

Fillon, F. (2016) Vaincre le totalitarisme islamique, Paris, Albin Michel.

France 3 (2017) 'Pièces à conviction: Président à tout prix, enquête sur les millions de la campagne'. 10 May 2017. https://www.youtube.com/watch?v=5Ks2NliFnzk Accessed 29 May 2017.

Giscard d'Estaing, V. (1985) Deux Français sur trois, Paris, Flammarion.

Haegel, F. (2002) 'Faire l’Union: la refondation des partis de droite après les élections de 2002'. Revue Française de Science Politique, 52.5-6, 561-76.

IFOP (2013) 'L’image de Nicolas Sarkozy auprès des Français'. 4-6 December. http://www.ifop.com/media/poll/2433-1-study_file.pdf Accessed 31 May 2017. 
IFOP (2014a) 'La candidature préférée des sympathisants UMP pour 2017'. 11-13

June. www.ifop.com/media/poll/2703-1-study_file.pdf Accessed 31 May 2017.

IFOP (2014b) 'Les intentions de vote pour l'élection présidentielle de 2017'. 28-30

October. www.ifop.com/media/poll/2826-1-study_file.pdf Accessed 31 May 2017.

IFOP (2016a) ‘Le regard des Français sur Alain Juppé’. 9-11 February.

http://www.ifop.com/?option=com_homepage Accessed 31 May 2017.

IFOP (2016b) 'L’intention de vote à la primaire organisée par Les Républicains'. 10-

17 November. http://www.ifop.com/media/poll/3560-1-study_file.pdf Accessed 1 June 2017.

IFOP (2016c) 'Le vote au second tour de la primaire des sympathisants de droite selon leur proximité à la Manif pour tous'. 21-23 November. http://www.ifop.com/media/poll/3569-1-study_file.pdf Accessed 1 June 2017.

IFOP (2016d) 'Le vote des sympathisants de droite catholiques à la primaire de la droite et du centre'. 21-23 November. http://www.ifop.com/media/poll/3568-1study_file.pdf Accessed 1 June 2017.

IFOP (2016e) ‘Suivi barométrique de la primaire organisée par Les Républicains dans la perspective du scrutin des 20 et 27 novembre 2016. Vague 9'. 31 October-14 November. www.ifop.com/media/poll/3554-1-study_file.pdf Accessed 1 June 2017.

IFOP (2017a) 'Les cartes de la présidentielle'. http://www.ifop.com/?option=com_cartos Accessed 3 June 2017. 
IFOP (2017b) 'Le vote des sympathisants de la Manif pour tous à l'élection présidentielle'. 16-19 April. http://www.ifop.com/media/poll/3742-1study_file.pdf Accessed 4 June 2017.

IFOP (2017c) 'Les profils des électeurs et les clefs du premier tour de l'élection présidentielle'. 23 April. http://www.ifop.com/media/poll/3749-1-study_file.pdf Accessed 4 June 2017.

IFOP (2017d) 'Le vote des électeurs confessionnels au $1^{\text {er }}$ tour de l'élection présidentielle'. 23 April. http://www.ifop.com/media/poll/3750-1-study_file.pdf Accessed 4 June 2017.

IFOP (2017e) 'Les profils des électeurs et les clefs du second tour de l'élection présidentielle'. 7 May. http://www.ifop.com/media/poll/3756-1-study_file.pdf Accessed 4 June 2017.

IFOP (2017f) ‘Les Français entre élection présidentielle et élections législatives'. 29_ 31 May. http://www.ifop.com/media/poll/3783-1-study_file.pdf Accessed 29 June 2017.

IFOP (2017g) 'Le profil des électeurs et les clefs du premier tour des élections législatives'. 11 June. http://www.ifop.com/media/poll/3791-1-study_file.pdf Accessed 29 June 2017.

IPSOS (2017a) 'Présidentielle 2017: les Français et la moralisation de la vie politique'. 30-31 March. http://www.ipsos.fr/decrypter-societe/2017-04-05-presidentielle2017-francais-et-moralisation-vie-politique Accessed 2 June 2017. 
IPSOS (2017b) ' $1{ }^{\text {er }}$ tour présidentielle 2017: sociologie des électorats et profil des abstentionnistes'. 19-22 April. http://www.ipsos.fr/decrypter-societe/2017-0423-1er-tour-presidentielle-2017-sociologie-l-electorat Accessed 4 June 2017.

IPSOS (2017c) ' $2^{\mathrm{e}}$ tour présidentielle 2017: sociologie des électorats et profil des abstentionnistes'. 4-6 May. http://www.ipsos.fr/decrypter-societe/2017-05-072nd-tour-presidentielle-2017-sociologie-electorats-et-profil-abstentionnistes, Accessed 5 June 2017.

Knapp, A. (2004) Parties and the Party System in France, Basingstoke, Palgrave.

Knapp, A., and Wright, V. (2006, $5^{\text {th }}$ edition) The Government and Politics of France, London, Routledge.

Knapp, A. (2014) 'En attendant Sarko? France’s Mainstream Right and Centre, 20122014'. Modern and Contemporary France, 22.4, 473-89.

Lacouture, J. (1985) De Gaulle. 2: Le Politique, Paris, Éditions du Seuil.

Les Républicains (2015) 'Nouveaux Statuts, mai 2015'. https://www.republicains.fr/textes_fondateurs Accessed 2 June 2017.

Madelin, P. (2001) Les Gaullistes et l'argent, Paris, L'Archipel.

Mair, P., Müller, W. and Plasser, F. (eds) (2004) Political Parties and Electoral Change, London, Sage.

Ministère de l’Intérieur (2017) 'Élections, Les Résultats, 2017’. www.intérieur.gouv.fr/Elections/Les-resultats Accessed 29 June 2017.

Pharr, S.J., and Putnam, R.D. (eds) (2000) Disaffected Democracies: What's Troubling the Trilateral Countries?, Princeton N.J., Princeton University Press. 
Primaire ouverte [de la droite et du centre] (2016) 'Les résultats'.

https://resultats.primaire2016.org/\#/total Accessed 3 June 2017.

Teinturier, B. (2017) 'Plus rien à faire, plus rien à foutre'. La vraie crise de la démocratie, Paris, Robert Laffont. 
Tables and figures

Table 1: Right-wing and extreme-right votes at intermediate elections, 2014-15

\begin{tabular}{|c|c|c|c|c|c|}
\hline Election & $\begin{array}{l}\text { UMP/Les } \\
\text { Républicains }\end{array}$ & UDI & $\begin{array}{l}\text { Other } \\
\text { Right }\end{array}$ & $\begin{array}{l}\text { Total } \\
\text { moderate } \\
\text { Right + } \\
\text { Centre }\end{array}$ & $\begin{array}{l}\text { Front } \\
\text { National }\end{array}$ \\
\hline $\begin{array}{l}\text { European, } 25 \\
\text { May } 2014\end{array}$ & 20.8 & 9.9 & 6.0 & 36.7 & 24.9 \\
\hline $\begin{array}{l}\text { Departmental, } \\
\text { first round, } 22 \\
\text { March } 2015\end{array}$ & $27.5^{*}$ & 1.6 & $7.2 * *$ & 36.2 & 25.2 \\
\hline $\begin{array}{l}\text { Departmental, } \\
\text { second round, } \\
29 \text { March } \\
2015\end{array}$ & $36.3 *$ & 1.6 & 6.9 & 44.8 & 22.2 \\
\hline $\begin{array}{l}\text { Regional, first } \\
\text { round, } 6 \\
\text { December } \\
2015\end{array}$ & $26.9 *$ & 0.4 & $4.5^{* *}$ & 31.8 & 27.7 \\
\hline Regional, & $40.2 *$ & & & & 27.1 \\
\hline
\end{tabular}




\begin{tabular}{|l|l|l|l|l|l|}
\hline second round, & & & & & \\
13 December & & & & & \\
2015 & & & & & \\
\hline
\end{tabular}

* Includes some centrists running as direct UMP/LR allies.

** Includes divers droite plus Debout la France.

Source: Ministère de l'Intérieur, 2017.

Table 2: Results of the Primary of the Right and the Centre, November 2016

\begin{tabular}{|c|c|c|}
\hline & $\begin{array}{l}20 \text { November: total vote } \\
4,298,097\end{array}$ & $\begin{array}{l}27 \text { November: total vote } \\
4,404,812\end{array}$ \\
\hline François Fillon & $44.1 \%$ & $66.5 \%$ \\
\hline Alain Juppé & $28.6 \%$ & $33.5 \%$ \\
\hline Nicolas Sarkozy & $20.6 \%$ & \\
\hline $\begin{array}{l}\text { Nathalie } \\
\text { Kosciusko- } \\
\text { Morizet }\end{array}$ & $2.6 \%$ & \\
\hline Bruno Le Maire & $2.4 \%$ & \\
\hline $\begin{array}{l}\text { Jean-Frédéric } \\
\text { Poisson }\end{array}$ & $1.4 \%$ & \\
\hline
\end{tabular}




\begin{tabular}{|l|r|r|}
\hline Jean-François & $0.3 \%$ & \\
Copé & & \\
\hline Blank or spoilt & 9,883 & 13,040 \\
ballots & & \\
\hline
\end{tabular}

Source: Primaire ouverte, 2016.

Figure 1: Voting intentions for three major candidates, November 2016-February 2017

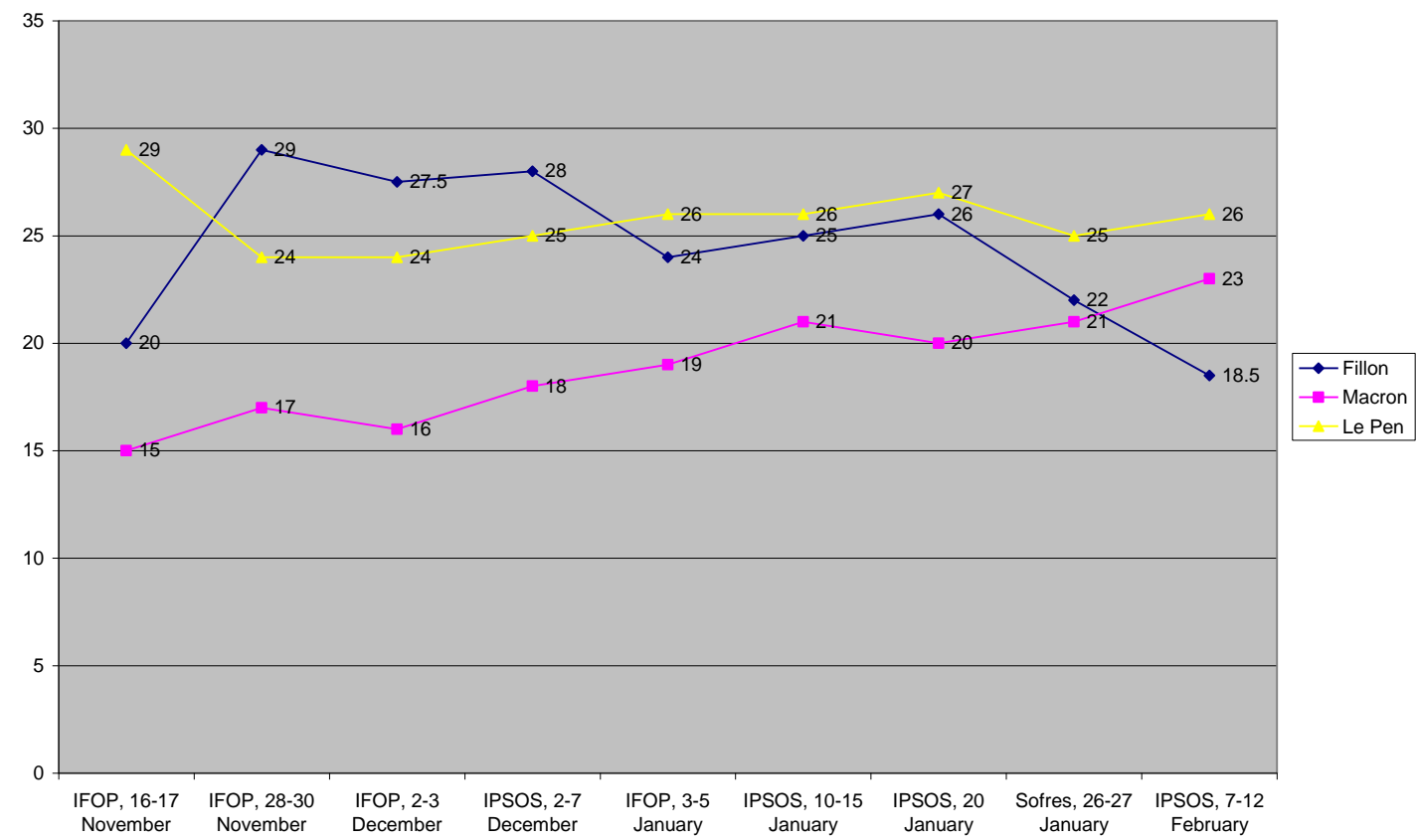

Table 3: Votes for the two leading presidential candidates, 2002 and 2017 


\begin{tabular}{|l|l|l|l|l|l|l|}
\hline 2002 & $1^{\text {st }}$ round, & $1^{\text {st }}$ & $2^{\text {nd }}$ round, & $2^{\text {nd }}$ & Net gain, & Net \\
& total vote & round, & total vote & ballot, & votes & gain, \\
$\%$ of & valid & & valid & & valid \\
\hline Jacques Chirac & $5,666,021$ & 19.88 & $25,537,894$ & 82.21 & $19,871,873$ & 62.33 \\
\hline Jean-Marie Le Pen & $4,804,772$ & 16.86 & $5,525,034$ & 17.79 & 720,262 & 0.93 \\
\hline votes & & votes & & \\
\hline Emmanuel Macron & $8,656,346$ & 24.01 & $20,743,128$ & 66.10 & $12,086,782$ & 42.09 \\
\hline Marine Le Pen & $7,678,491$ & 21.30 & $10,638,475$ & 33.90 & $2,959,984$ & 12.60 \\
\hline
\end{tabular}

Source: Ministère de l'Intérieur, 2017.

Table 4: Where the votes went, 7 May 2017 (as \% of first-ballot vote share)

Fillon Macron Le Pen Abstention, Dupont- Macron Le Pen Abstention,

voters, 23

April

etc.

poilt ballot. Aignan

voters, 23

April

IPSOS

$48 \quad 20$

32 IPSOS

27

30

43

IFOP

$51 \quad 23$$$
26
$$

26

IFOP

26

46

spoilt

ballot. etc. 
Sources: IPSOS, 2017c; IFOP, 2017e. 